\title{
BANKARSTVO U SENCI KAO POTENCIJALNI FAKTOR NESTABILNOSTI FINANSIJSKIH SISTEMA
}

\author{
Vladimir Mirković1, \\ Zdenka Dudić2, \\ Branislav Dudić ${ }^{3}$
}

\author{
${ }^{1}$ Narodna banka Srbije, \\ Beograd, Srbija \\ ${ }^{2}$ Fakultet tehničkih nauka, \\ Novi Sad, Srbija \\ ${ }^{3}$ Univerzita Komenského v \\ Bratislave, Fakulta managementu, \\ Bratislava, R. Slovačka
}

\begin{abstract}
Apstrakt:
Poslednju deceniju XXI veka, naročito nakon globalne finansijske krize, karakteriše intenziviranje procesa prelaska sa tradicionalnih bankarskih institucija na nebankarske institucije, odnosno na tzv. "bankarstvo iz senke" (shadow banking). Odbor za finansijsku stabilnost (Financial Stability Board - FSB) je definisao pojam "bankarstva iz senke" i time značajno doprineo identifikovanju osnovnih pokretača promena, koje sa sobom nose prisustvo nebankarskih institucija u segmentima tradicionalnog bankarstva. Osnovni pokretači promena se mogu identifikovati u sferama: regulatornih zahteva, tehnološkog napretka i povoljnog makroekonomskog okruženja. "Bankarstvo u senci” je prisutno na tržištima razvijenih zemalja i ostvaruje natprosečne volumene ukazujući na njihov značaj. Iako su prema Zakonu o bankama Republike Srbije, banke jedine institucije koje se mogu baviti davanjem kredita i izdavanjem platnih kartica kao i prikupljanjem depozita, postoji verovatnoća da će "bankarstvo u senci" biti prisutno i na domaćem tržištu. U ovom radu biće prikazane karakteristike "bankarstva u senci", trendovi u kretanjima i analiza njegovog potencijalnog uticaja na stabilnost finansijskih sistema. Rad je namenjen stručnjacima iz oblasti bankarskog i finansijskog menadžmenta, kao i široj naučnoj zajednici koja se bavi pitanjem regulative oblasti koje su trenutno izvan dometa zvaničnih regulatornih organa (poput "bankarstva u senci").
\end{abstract}

Ključne reči:

bankarstvo u senci, tradicionalno bankarstvo, inovacije, stabilnost, finansijski sistem.

\section{UVOD}

Poslednju dekadu XXI veka, pogotovo u periodu posle globalne finansijske krize, obeležio je intenzivni proces transformacije od tradicionalnih bankarskih institucija ka nebankarskim institucijama, poznat kao "bankarstvo iz senke" (shadow banking). Odbor za finansijsku stabilnost (Financial Stability Board - FSB) je definisao pojam bankarstva u senci u oktobru 2011. godine kao "sistem posredovanja u sferi kreditiranja koji uključuje lica i poslovne aktivnosti van okvira tradicionalnog bankarstva" (Financial Stability Board, 2011). Pored pomenute definicije, još jedna vrlo često citirana definicija banaka u senci govori da je reč o "finansijskim posrednicima koji sprovode ročnu, kreditnu i likvidnu transformaciju bez korišćenja likvidnih sredstava centralne banke ili kreditnih garancija javnog sektora" (Pozsar et al., 2010). Bankarstvo u senci ne podrazumeva ilegalne, već nedovoljno kontrolisane institucije, npr. hedž fondove i finansijske kompanije u zemljama u razvoju, koje prikupljaju novčana sredstva od investitora i plasiraju ih preuzimajući ulogu tradicionalnih banaka. Dakle, značenja sintagme "bankarstvo u senci" nije nužno loše, već ukazuje na alternativne načine finansiranja koji se razlikuju od tradicionalnog bankarstva, i dolaze do izražaja kada postojeći kanali finansiranja privrede postanu nedovoljni.

Bankarstvo u senci je značajan globalni fenomen, koji obuhvata oko 25\% ukupnih svetskih transfera novaca između štediša i finansijskih institucija koje se bave odobravanjem sredstava, prema proceni Međunarodnog monetarnog fonda. Prema proceni kreditne rejting agencije Moody's, transakcije kineskih banaka u senci i čine 65\% ukupnog GDP-a zemlje u 2014. godini (Jiang, 2015). Investitori se opredeljuju za banke u senci,
Korespondencija:

Vladimir Mirković

e-mail:

vladamirkovic@orion.rs 
nastojeći da ostvare više stope prinosa u odnosu na stope prinosa koje omogućavaju tradicionalne banke. Banke u senci predstavljaju paralelni finansijski sistem, koji obuhvata aktivnosti kreditiranja, ali se nalaze izvan domašaja zvaničnog bankarskog sistema (Ekapija, 2015). Banke u senci pribavljaju sredstva od investitora na kratak rok, a plasiranje sredstava vrše dugoročno, što može ozbiljno da ugrozi funkcionisanje globalne ekonomije u slučaju nastupanja nepredviđenih kriznih događaja i masovnog povlačenje novca, i u krajnjoj liniji da dovede do kraha celokupnog sistema (European Central Bank, 2012). S tim u vezi, jedno od osnovnih nastojanja u EU se odnosi na mogućnost regulisanja tržišta banaka u senci, čak i kroz ideje koje podrazumevaju proširenje obuhvata kapitalnih zahteva na nedepozitne kompanije.

U Republici Srbiji bankarstvo u senci trenutno ne postoji, štaviše ne postoji zakonska mogućnost da se bilo koje lice bavi aktivnostima koje su definisane kao aktivnosti kojima se isključivo bave banke. Zakon o bankama u članu 5, st. 1 i 2 reguliše oblast onih institucija koje se mogu baviti poslovima kao što su prikupljanje depozita i davanje kredita. "Niko osim banke ne može se baviti primanjem depozita. Niko osim banke ne može se baviti davanjem kredita i izdavanjem platnih kartica, osim ako je za to ovlašćen zakonom" (Zakon o bankama, 2015). Sa druge strane, uticaj savremenih informacionokomunikacionih tehnologija i inovacija aktuelne faze srpskog bankarstva je jasno uočljiva. Težište konkurentske borbe između banaka se pomera na tehnološki aspekt, a tehnologija postaje strateška funkcija banaka. Mobilno bankarstvo ostvaruje značajan prodor na tržištu, a konkretni primeri Telenor i MTS banke predstavljaju "paradigmu budućeg pravca razvoja mobilnog bankarstva” (Mirković \& Lukić, 2015, str. 308) kao i opšteg razvoja bankarstva u novom, digitalnom dobu.

\section{OSNOVNA OBELEŽJA BANKARSTVA U SENCI}

Uloga bankarstva u senci u svetskom finansijskom sistemu je postala očigledna tokom globalne finansijske krize, usled prisutnosti i sistemskog rizika. Ukoliko bismo analizu zasnovali na razlozima koji su doveli do toga da bankarstvo u senci danas predstavlja značajnu i vrlo prisutnu snagu, neophodno je istaći da su osnovni mehanizmi ponude i tražnje u finansijskom sektoru bitno izmenjeni u poslednjoj dekadi. Jedan deo promena jeste rezultat pada kamatnih stopa, a drugi deo promena potiče od informaciono-tehnološkog mehura koji je doveo do značajnog zaokreta u XXI veku. Posledično, ove promene menjaju poslovne modele banaka u cilju održavanja nivoa konkurentnosti i zadovoljavanja potreba oličenih u vidu stope prinosa i niskog rizika.

Generalno, možemo identifikovati tri glavna pokretača u zaokretu ka bankarstvu u senci, a to su:

- striktni regulatorni zahtevi (uključujući i strožije kapitalne zahteve);
- proces razduživanja (deleveraging), kao posledica regulatornih zahteva; i

- tehnološki napredak i povoljno makroekonomsko okruženje.

Kada je reč o regulatornim zahtevima, neophodno je istaći da se kao glavni cilj uvođenja Bazelskih standarda (naročito Bazel III standarda), kao opštih okvira za regulisanje funkcionisanja bankarskih sistema, navodi unapređenje kvaliteta regulatornog kapitala i jačanje kapitalnih zahteva, kao i pomeranje fokusa na osnovni akcijski kapital i strože zahteve u pogledu: zaštitnih slojeva kapitala, leveridž racija, održavanja likvidnosti i rizika druge ugovorne strane (counterparty risk) za aktivnosti iz knjige trgovanja. Istorijski posmatrano, uvođenje Bazel I standarda 1988. godine (kao odgovor na bankarsku krizu 80-ih godina prošlog veka) je imalo za cilj uvođenje kapitalnih zahteva za same banke. Strožiji kapitalni zahtevi su predstavljali poteškoću za same banke u smislu smanjenih mogućnosti ostvarivanja visoke stope prinosa (pre svega na kapital) i smanjene konkurentnosti, u odnosu na ostale tržišne učesnike, koji ne podležu takvim regulatornim zahtevima. U tom smislu, banke su prinuđene da pronalaze nove načine umanjivanja rizika uz očuvanje kapitalne baze i porast profitabilnosti (Bundgard \& Jorgensen, 2015). Za ostvarivanje navedenih ciljeva, neophodno je preneti rizik na spoljašnje investitore koji su voljni da preuzmu rizik (kroz prošireni sistem kreditnog posredovanja), ili se opredeliti za kupovinu finansijskih instrumenata za osiguranje od rizika (poput CDS derivata - credit default swap). Sve prethodno izneto nameće značajan pritisak na same banke u segmentu održavanja što višeg nivoa kapitala, pri čemu su dostupni ograničeni izvori finansiranja, što dovodi do procesa razduživanja u bankarskom sistemu. Jedan od najčešćih načina razduživanja banaka jeste putem smanjenja kreditne aktivnosti, što sa svoje strane utiče na ulazak novih tržišnih učesnika sa željom da zauzmu tržišnu nišu u cilju zadovoljavanja potreba privrede; odnosno, stvaranje dodatnih izvora finansiranja i ponuda alternativnih investicionih mogućnosti u odnosu na depozite banaka.

Nebankarske institucije su u mogućnosti da iskoriste ukazanu priliku kreiranu novim regulatornim zahtevima, ali sa druge strane nemaju dovoljno kapaciteta za upravljanje rizicima kao što je to slučaj sa tradicionalnim bankarskim institucijama. Efekat prelaska sa kreditiranja putem bankarskih proizvoda na alternativne izvore finansiranja, imaće izražen uticaj na Evropu, čija se privreda 75-80\% finansira bankarskim sredstvima i gde je prelazak na druge oblike finansiranja još u početnoj fazi, sa tendencijom rasta (Wehinger, 2012). Poređenja radi, privredna društva u SAD $25 \%$ svojih aktivnosti finansiraju putem banaka, i u ovoj zemlji je prelazak na alternativne oblike finansiranja već u poodmakloj fazi. Takođe, tokom procesa razduživanja konsultanti za upravljanje ličnom imovinom (wealth management) stiču veliku popularnost, jer pored savetodavnih usluga, pružaju usluge posredovanja između zainteresovanih investitora i njihovih klijenata. 
Prema istraživanju sprovedenom od strane Međunarodnog monetarnog fonda (IMF, 2014), vrednost transakcija koje pokriva bankarstvo u senci iznosi između 15 i 25 triliona dolara u SAD-u, između 13,5 i 22,5 triliona dolara u evrozoni, i oko 7 triliona dolara u zemljama u razvoju.

Inovacije u tehnološkom segment su omogućile nove načine obavljanja finansijskih usluga, i time pojačale pritisak na tradicionalni poslovni model banaka. Reč je o permanentnom inoviranju, što u krajnjoj liniji dovodi do promene strukture u finansijskoj industriji. Glavni pokretači ovih promena su tehnološke inovacije u sferi finansija, poznatije kao FinTech, koje koriste naprednu tehnologiju i programska rešenja u cilju što efikasnijeg izvršenja finansijskih usluga. Pored toga, oni pružaju finansijske usluge putem onlajn platformi koje direktno povezuju investitore i dužnike u cilju stvaranja novih investicionih mogućnosti, u svetu poznatiji pod nazivima peer to peer lending i crowdfunding. Peer to peer lending predstavlja praksu pozajmljivanja novčanih sredstava putem onlajn servisa koji direktno povezuju investitore i dužnike. Kraudfanding je praksa prikupljanja novčanih sredstava za finansiranje nezavisnih projekata putem interneta, od strane velikog broja zainteresovanih lica.

Putem onlajn platforme ovi finansijski posrednici nude kredite po nižim kamatnim stopama, jer nemaju značajne fiksne troškove, smanjuju rizik prikupljanjem dodatnih informacija o dužnicima, i odbijanjem dužnika kod kojih je velika verovatnoća da neće biti u mogućnosti da izmire svoje obeveze. Dodatna prednost jeste da su ovi izvori finansiranja dostupni većem broju zainteresovanih lica, zbog manjih ograničenja i manje strogih regulatornih zahteva. Iz navedenih razloga, peer to peer lending kao način kreditiranja spada u najbrže rastući sektor nebankarske industrije. Pored toga, pojava bitkoina (bitcoin) kao sredstva elektronskog plaćanja, obezbedila je redefinisanje funkcionisanja platnih sistema i sistema poravnanja, predstavljajući

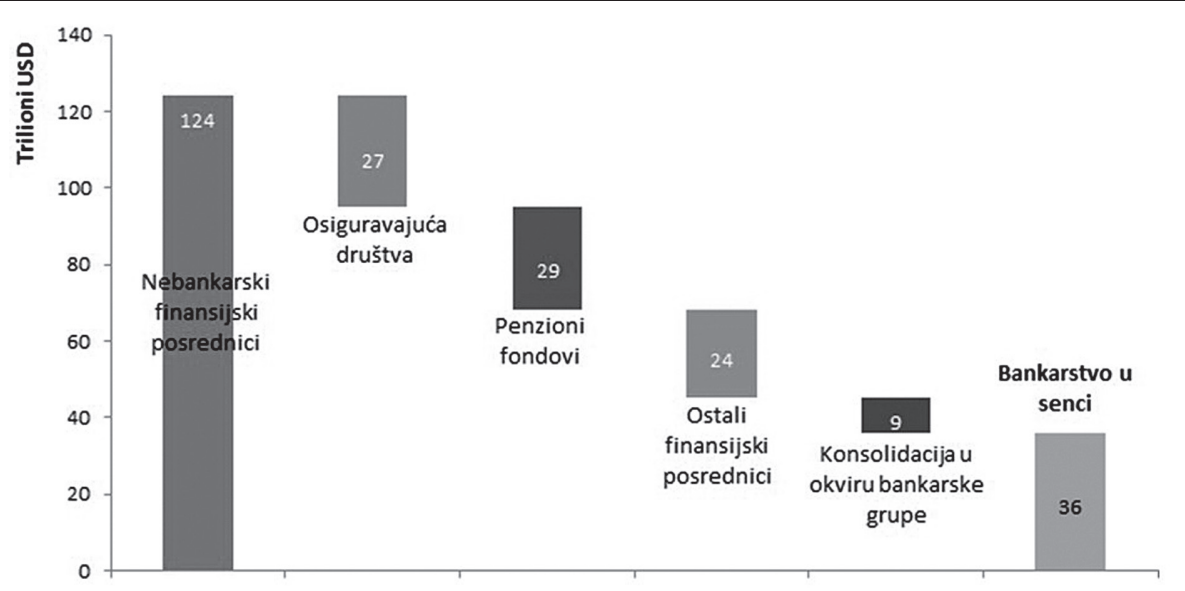

Slika 1. Obim bankarstva u senci na globalnom nivou u 2014. godini (www.fsb.org)
Prema izveštaju Odbora za finansijsku stabilnost (FSB) ukupna aktiva finansijskih institucija koja se tretira kao bankarstvo u senci, prema pristupu ekonomskih funkcija na tlu 26 zemalja, kontinuirano ukazuje na rastući trend, što uz povećanje za 1,1 trilion USD dovodi do iznosa od 36 triliona USD koje čini bankarstvo u senci. Zbirna aktiva banaka u senci se $u$ poslednjih pet godina (počev od 2011. godine) $u$ proseku povećavala za 1,3 triliona USD svake godine.

Ukupan obim svih transakcija koje se kandiduju za transakcije sa karakteristikama bankarstva u senci se postepeno sužavaju i svode na "čiste" transakcije bankarstva u senci. Pomenuto sužavanje ukupnog obima nebankarskog finansijskog posredovanja se vrši iz nekoliko razloga:

- svi penzioni fondovi i pojedina osiguravajuća društva ne učestvuju u kreiranju kreditne aktivnosti;

- pojedini finansijski posrednici (investicioni fondovi koji ulažu u akcije) ne predstavljaju kreditne posrednike niti doprinose ukupnom iznosu izloženosti banaka u senci;

- pojedine banke pripadaju bankarskim grupacijama (predstavljaju njihove subsidijare) tako da se kapitalni zahtevi kod ovih institucija propisuju na nivou Grupe;

- nakon umanjenja za gore navedene stavke dolazi se do čistog iznosa onih aktivnosti koje predstavljaju bankarstvo u senci - slika 1 (Financial Stability Board, 2014). na taj način alternativu tradicionalnom bankarstvu. Jedan od razloga zašto se brži tehnološki napredak javio u finansijskoj industriji, u odnosu na ostale industrije, jeste veće poverenje klijenata u tradicionalne banke. $\mathrm{U}$ tom smislu, globalna finansijska kriza i pad poverenja u banke dodatno je doprineo razvoju nebankarskih tržišnih učesnika. Pogodno makroekonomsko okruženje dovelo je do traganja za novim investicionim mogućnostima koje nose veći prinos, i omogućavaju ulazak novih učesnika koji na drugačiji način ocenjuju rizični profil dužnika. Upravo iz tog razloga, iz perspektive regulatora, potrebno je dalje razvijati i unapređivati regulatorni okvir za poslovanje FinTech kompanija.

Tabela 1. Aktiva finansijskih posrednika na kraju 2014. godine

\begin{tabular}{lccc}
\hline $\begin{array}{c}\text { Vrsta finansijske } \\
\text { institucije }\end{array}$ & $\begin{array}{c}\text { Obim } \\
\text { (u milionima } \\
\text { USD) }\end{array}$ & $\begin{array}{c}\text { Rast u 2014. } \\
(\mathrm{u} \%)\end{array}$ & $\begin{array}{c}\text { Prosečna godišnja } \\
\text { stopa rasta } \\
(2011-2014) \mathrm{u} \%\end{array}$ \\
\hline $\begin{array}{l}\text { Tradicionalne } \\
\text { banke }\end{array}$ & 135 & 6,4 & 5,6 \\
\hline $\begin{array}{l}\text { Ostali finansijski } \\
\text { posrednici }\end{array}$ & 68 & 9 & 6,3 \\
\hline Banke u senci & 36 & 10,1 & 6,3 \\
\hline
\end{tabular}

Izvor: FSB (www.fsb.org) 
Ukoliko se primenjuje nešto drugačiji uzorak od 20 država i uključi tržište evrozone kao celine, onda je ukupna vrednost tržišta banaka u senci 80 triliona USD (77 triliona EUR) u 2014. godini, što je za 1,6 triliona USD više nego u 2013. godini. Porast vrednosti aktive zastupljene u bankama u senci je istovremeno praćen neznatnim padom aktive zvaničnih globalnih bankarskih sistema. Posmatrajući udeo bankarstva u senci u ukupnom svetskom GDP-u primetno je povećanje sa $55 \%$ u 2012. godini na 59\% u 2014. godini, s obzirom da je kontinuiran rast bankarstva u senci poslednjih godina (uglavnom od 2010. godine do danas) nadmašio kretanje svetskog GDP-a. Rast bankarstva u senci se delimično može objasniti niskom početnom osnovom, naročito u zemljama koje karakteriše nedovoljan stepen razvijenosti finansijskih sistema. Pored toga, neophodno je uzeti u obzir da svako povećanje i promena faktora sistemskog rizika (npr. ročna transformacija) mogu nastati usled značajne ekspanzije kredita koje omogućava nebankarski sektor u odnosu na GDP.

U cilju ograničavanja obima transakcija koje pokrivaju banke u senci, Evropsko bankarsko telo (EBA - European Banking Authority) je razvilo niz smernica koje podrazumevaju utvrđivanje zbirnih limita ili užih pojedinačnih limita za izloženosti lica koja čine bankarstvo u senci i sprovode bankarske aktivnosti izvan zvaničnih (regulatornih) okvira. Razlog za ovakvo postupanje EBA se krije u iskustvima iz prošlosti, koja su pokazala da je transfer rizika iz bankarskog sistema u senci na regularni bankarski sistem, tokom finansijske krize, doveo u pitanje stabilnost celokupnog svetskog finansijskog sistema. Posmatrano iz mikroprudencijalnog ugla, bankarstvo u senci ne podleže istim standardima prudencijalne regulative kao što je to slučaj sa regularnim bankarskim sistemima, imajući u vidu da lica prepoznata kao banke u senci ne obezbeđuju zaštitu investitora u slučaju kolapsa banke u senci, kao i da banke u senci nemaju pristup likvidnim sredstvima dobijenim od strane centralnih banaka kao što je to slučaj sa tradicionalnim bankama.

Kako banke u senci sprovode aktivnosti koje su vrlo slične tradicionalnim bankama, može se izneti sud da su banke u senci rizičnije, te da je određeni vid limitiranja izloženosti ka bankama u senci neophodan, kako bi se uvela disciplina na tržištu i predupredio eventualni negativni scenario u slučaju vanrednih događaja, poput finansijske krize. Makroprudencijalni aspekt ukazuje da izloženosti ka bankama u senci mogu biti predmet dodatnog praćenja iz nekoliko razloga. Jedan od bitnijih i najčešće isticanih razloga jeste arbitražno ponašanje samih banaka u cilju ostvarivanja što većeg iznosa profita, te se iz zvaničnih bankarskih krugova određene tradicionalne banke mogu preorijentisati na bankarstvo u senci, dovodeći u pitanje stabilnost celokupnog bankarskog sektora.

Kod banaka u senci je moguće identifikovati glavne izvore rizika koje generiše ova kategorija banaka i to:

- Problemi likvidnosti i povlačenja sredstava - Kako banke u senci nisu predmet sveobuhvatne i zvanične supervizije regulatornih organa, one su istovremeno $\mathrm{u}$ većoj meri pogođene određenim negativnim događajima poput: povlačenja depozita usled panike, prevremene otplate usled nedovoljnog poverenja u funkcionisanje sistema u slučaju krize, likvidnosnih problema koji potiču iz kreditne izloženosti, nepodudaranja rokova dospeća aktivnih i pasivnih stavki itd. Pri čemu banke u senci probleme likvidnosti mnogo teže rešavaju, jer nisu korisnici sredstava centralne banke, koja se odobravaju zvaničnim bankarskim sistemima u slučaju krize likvidnosti.

- Međusobna povezanost i efekat "prelivanja" - Banke u senci nastoje da ostvare visok stepen povezanosti sa zvaničnim bankarskim sektorom bilo kroz obavljanje transakcija sa ovim sektorom bilo kroz povezanost $\mathrm{u}$ vlasničkoj strukturi. U uslovima šoka, upravo pomenute povezanosti banaka u senci sa regularnim bankarskim sistemima mogu biti generator sistematskog rizika kroz efekat "zaraze" koji se prenosi između dva posmatrana sektora.

- Visok stepen zaduženosti i procikličnost - Nepodudaranje rokova dospeća aktive i pasive i rizik likvidnosti su dodatno povećani mogućnošću banaka u senci da se angažuju u određenim aktivnostima koje imaju visok nivo leveridža tj. koje predstavljaju vrlo rizične aktivnosti. U slučaju nastupanja negativnih događaja, znatno je teže institucijama koje su u velikoj meri bile opredeljene na aktivnosti sa visokim leveridžom i visokom rizikom, kao što je to slučaj kod banaka u senci. Samim tim, bankama u senci je mnogo teže da obezbede stabilne izvore finansiranja.

- Složenost - Kompleksna priroda upravljanja i vlasništva nad bankama u senci, kao i njihovih veza sa regularnim bankarskim sektorom, predstavlja izvor nestabilnosti u uslovima nastupanja nepredviđenih događaja (European Banking Authority, 2015).

\section{EMPIRIJSKI NALAZI O BANKARSTVU U SENCI, NA PRIMERU KINE I IRSKE}

Stepen u kojem su banke u senci postale neizostavni segment savremenog finansijskog sistema se najjednostavnije može sagledati kroz određene empirijske podatke vezane za bankarstvo u senci konkretnih zemalja. U ovom radu autori se bave pitanjem bankarstva u senci na primerima privrede i finansijskih sistema Kine i Irske.

Kinu karakteriše visoki stepen prisustva bankarstva u senci, što direktno utiče na široku rasprostranjenost likvidnih sredstava na tržištu koju obezbeđuju upravo banke u senci. U Kini su identifikovana tri glavna pokretača porasta vrednosti transakcija banaka u senci:

- težnja investitora za višim stopama prinosa,

- potreban kapital za razvoj sektora malih i srednjih preduzeća,

- regulatorni zahtevi u odnosu na tradicionalne banke. 
Gotovo polovinu svih bankarskih instrumenata koji imaju tretman bankarstva u senci Kine u 2014. godini čine dve dominantne kategorije: proizvodi za upravljanje ličnom imovinom (proizvodi wealth menadžmenta) i "povereni krediti" (entrusted loans). Upravo zahvaljujući osnovnim karakteristikama proizvoda za upravljanje ličnom imovinom, oni se u praksi često tretiraju kao zamena za tradicionalne oročene bankarske depozite. "Povereni krediti" imaju udeo od 22\% u ukupnim transakcijama bankarstva u senci i podrazumevaju produžene kreditne aranžmane između samih preduzeća, koje često koriste banke ili druge finansijske institucije kao posrednike. Pošto obuhvataju vanbilansne transakcije, ovi krediti nemaju uticaj na profil kreditnog rizika same banke niti na pokazatelj odnosa kredita i depozita (loan-to-deposit ratio).

Centralna banka Kine je ovu vrstu kredita dozvolila počevši od 2001. godine, ali upravo nedostatak transparentnosti u pogledu rizičnog profila banaka otežava mogućnost donošenja logičnih zaključaka o tome da li ekonomiju Kine karakteriše "pregrejana" tražnja za kreditima ili je reč o prezaduženoj ekonomiji, kao i nemogućnost realnog sagledavanja da li se kvalitet kreditnog portfolija poboljšava ili pogoršava. "Povereni krediti" se uglavnom javljaju u dva oblika i to kao: krediti afilijacijama i ostali "povereni krediti". Krediti afilijacijama (subsidijarima, dobavljačima i drugim poslovnim partnerima) se odnose na visoko profitne korporacije i podrazumevaju da su troškovi kapitala za velika preduzeća znatno jeftiniji nego za afilijacije, tako da velika preduzeća mogu ostvariti značajne uštede ili odobriti kredite onim preduzećima koja se ne mogu kvalifikovati za kredite tradicionalnih kineskih banaka. Ostali "povereni krediti" se odobravaju kao dodatak nisko-profitnim poslovima, kroz odobravanje kredita licima sa kojima banke nemaju direktnu povezanost.

I pored značajnog obima transakcija bankarstva u senci u Kini, može se oceniti da bankarstvo u senci nije ozbiljna pretnja po stabilnost finansijskog sistema Kine, koje je manjeg obima i relativno jednostavno strukturirano, u poređenju sa rizicima u pojedinim zemljama zapada. Istovremeno treba imati u vidu da je inherentno postojanje pojedinih vrsta rizika u bankarskom sistemu u senci u Kini. Prvo, liberalna upotreba derivata i izloženost sektorima koji su potencijalni izvor finansijskih kriza ne predstavlja najveći rizik, već realna opasnost da investitori prestanu sa kupovinom proizvoda wealth menadžmenta, što će značiti da banke nemaju alternativno rešenje osim da zaustave kreditiranje novih preduzetnika u posmatranoj zemlji.

Drugo, strukturni rizik za Kinu predstavlja i ročna neusklađenost između kratkoročnih investicija i dugoročnih kredita. Prinosi na proizvode wealth menadžmenta su zasnovani na aktivi koja je u osnovi tih izvedenih proizvoda, ali je trajanje proizvoda znatno kraće. Prosečan rok dospeća je do 3 meseca, iako se posmatrani krediti mogu primeniti na stambene kredite ili na neke druge oblike dugoročnih kredita. Treće, iako je rizik neizmirenja obaveza od strane dužnika u Kini na niskom nivou, treba imati u vidu da je rizični profil najvećih dužnika (malih i srednjih preduzeća i preduzetnika) uglavnom viši od važećeg bankarskog proseka za klijente. Konkretno, rizik se povećava u sektoru nekretnina i infrastrukturnom sektoru, za koje je prema proceni Moody's odobrena 1/3 ukupnih kredita banaka u senci. Uprkos činjenici da ne postoje garancije za pomenute kredite, kineski investitori gotovo jednodušno očekuju da banke ili država pokriju eventualno nastale gubitke.

Posle petogodišnjeg uzastopnog rasta od 30\% i više svake godine, kinesko bankarstvo u senci je 2015. godine bilo suočeno sa znatno umanjenom dinamikom rasta, koja je prema proceni Moody's na nivou stope rasta nominalnog GDP-a Kine. Usporeni tempo rasta bankarstva u senci se može objasniti sledećim razlozima:

- potezi zvaničnog bankarskog sektora Kine da se privuku proizvodi i klijenti koji su prethodno bili usmereni na bankarstvo u senci;

- napori države da kontroliše najrizičnije aspekte bankarstva u senci;

- mogućnost popuštanja određenih oštrih regulatornih mera koje su ograničavale aktivnost banaka;

- nedovoljna tražnja za kreditima. Prema podacima centralne banke Kine kreditna aktivnost u 2014. godini je po svim osnovama bila smanjena za $6 \%$ u odnosu na prethodnu godinu. Usporeni ekonomski rast je naročito primetan u oblasti nekretnina, koja je i glavni izvor bankarstva u senci (Jiang, 2015).

Dva potpuno suprotna scenarija ukazuju na buduća kretanja kineskog bankarstva u senci, pri čemu su ključni učesnici u pomenutim scenarijima same banke. Prvi scenario podrazumeva da se banke povlače iz senke, odnosno da banke na osnovu analize utvrde da im je vrlo isplativo da kreditiraju postojeće dužnike u senci. Proizvodi banaka u senci se tada mogu činiti manje značajnim za banke, jer će obavljanje tradicionalnih bankarskih aktivnosti (davanje klasičnih bankarskih kredita) zahtevati znatno manje sredstava i napora za realizaciju. Posledično, predviđena stopa prinosa investicija u proizvode za upravljanje ličnom imovinom se može značajno smanjiti, ukoliko banke i druga lica iz finansijskog sektora procene da su takvi proizvodi trenutno manje atraktivna alternativa od tradicionalnih bankarskih proizvoda.

Drugi scenario podrazumeva da će se zvanične bankarske institucije opredeliti za strategiju preuzimanja banaka u senci. Kako četiri najveće kineske banke čine oko polovinu tržišnog učešća proizvoda za upravljanje ličnom imovinom, nije nelogično da će banke biti motivisanemogućnošću da pomenutim proizvodima obogate svoju ponudu i na taj način privuku nove deponente. Uostalom, pojedine velike kineske banke su u svojim bilansima zadržale određene proizvode wealth menadžmenta, čime jasno ukazuju da njihova namera nije izbegavanje bilo kojeg vida regulatornih okvira. Kineske banke proizvode wealth menadžmenta vide kao značajan oblik 
prihoda, koji se može i dalje uvećavati pod pretpostavkom privlačenja novih investitora. Nedvosmisleno je da će bankarstvo u senci u budućnosti menjati svoju formu, tako da će ili iščeznuti ili prerasti u sofisticiranije rešenje koje je već patentirano u pojedinim zapadnim državama, npr. kroz sekjuritizaciju ili derivate koji još nisu premet ograničavanja i organizovanog praćenja od strane samih banaka.

Irsku karakteriše izraženo visoko učešće sektora ostalih finansijskih posrednika u odnosu na GDP države, obuhvatajući široku lepezu lica i aktivnosti. Ukupna vrednost svih transakcija u okviru irskih banaka u senci je iznosila 2.250 milijardi EUR na kraju 2014. godine, pri čemu je najveći pojedinačni udeo činila ekonomska funkcija koja se odnosi na investiciona preduzeće posebne namene i kreditno posredovanje na bazi sekjuritizacije. Kako je najveći deo aktive i pasive ovih lica smešten izvan Irske, sektor banaka u senci dobija međunrodni karakter i nameće se potreba za međunarodnom saradnjom u cilju ocene ukupnog potencijala koji se može ugraditi u sistemski rizik. Iz regulatornog ugla, investicioni fondovi su predmet zvanične regulative, dok preduzeća koja se bave sekjuritizacijom nisu deo zvaničnog regulatornog okvira i nalaze se izvan njenog domašaja. Unapređenje u oblasti praćenja i analize irskog bankarstva u senci podrazumeva znatne izmene u postojećoj regulativi, i nameće potrebu koordinacije sa drugim jurisdikcijama koje su nadležne za pokrivanje svih kategorija bankarstva u senci.

Finansijski sektor Irske na kraju 2014. godine beleži vrednost od 4.054 mlrd EUR. Strukturu finansijskog sektora Irske najvećim delom čine kreditne institucije kao regularni kanal (773 mlrd EUR), dok se preostalih 81\% aktivnosti nalazi kod banaka u senci, odnosno, izvan regulatornih okvira finansijskog sistema. Svodeći strukturu bankarstva u senci u Irskoj na one institucije koje imaju najveće učešće izdvajaju se: investicioni fondovi (vrednost transakcija od 1.634 mlrd EUR), fondovi novčanog tržišta (394 mlrd EUR), preduzeća posebne namene (402 mlrd EUR), osiguravajuća društva ( $250 \mathrm{mlrd}$ EUR) i ostali finansijski posrednici (498 mlrd EUR). Očekuje se da će visok udeo kategorije ostalih finansijskih posrednika (16\%) iskazati slične performanse kao i u drugim zemljama u kojima je prisutno bankarstvo u senci, te će se njihovo relativno učešće vremenom smanjivati (Financial Stability Board, 2015).

Irski investicioni fondovi su u periodu između 2011. i 2014. godine udvostručili vrednost transakcija (sa $819 \mathrm{mlrd}$ EUR na 1.634 mlrd EUR). Ovi fondovi su se uglavnom rukovodili konzervativnom investicionom strategijom koju predviđa regulativa Evropske unije, pri čemu je neophodno istaći da je većina investicionih menadžera ovih fondova locirana izvan jurisdikcije centralne banke Irske (koja daje ovlašćenja za rad i vrši superviziju irskih investicionih fondova) što znači da podležu superviziji i monitoringu nadležnih nacionalnih supervizorskih tela. Hedž fondovi obuhvataju oko $10 \%$ ukupnih investicionih fondova (posmatrano prema neto vred- nosti aktive) i čine oko polovine ukupne zaduženosti sektora. Najveći deo zaduženosti (leveridža) sektora investicionih fondova se odnosi na transakcije derivatima - 222 mlrd EUR (bruto iznos) kao i repo/reverse repo transakcije, transakcije davanja ili uzimanja u zajam hartija od vrednosti i transakcije kreditiranja trgovine hartijama od vrednosti (ili security financing transactions - SFT) - 42 mlrd EUR (Financial Stability Board, 2015).

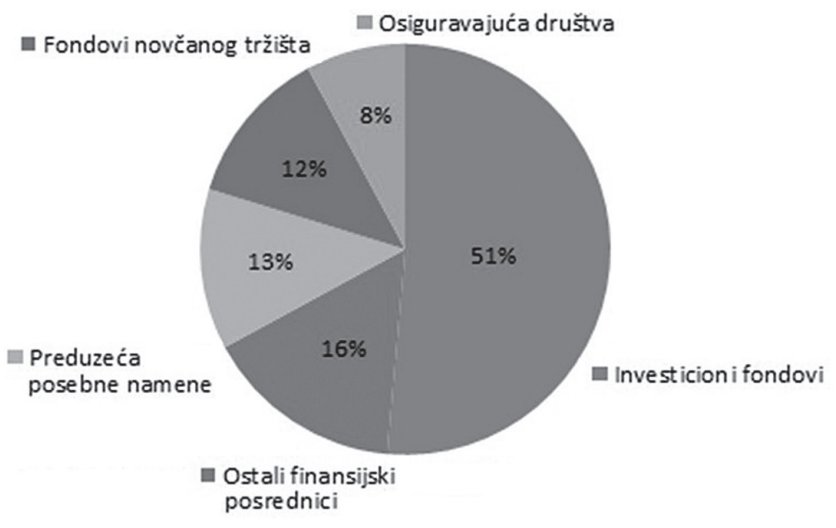

Slika 2. Struktura nebankarskih institucija u Irskoj u 2014. godini (www.fsb.org)

Fondovi irskog novčanog tržišta su u poslednje tri godine porasli za 58 mlrd EUR ili 20\%, tako da na kraju 2014. godine iznose 395 mlrd EUR. Fondovi novčanog tržišta ulažu u instrumente tržišta novca i u repo/reverse repo transakcije, transakcije davanja ili uzimanja u zajam hartija od vrednosti i transakcije kreditiranja trgovine hartijama od vrednosti. Posledično, ovi fondovi predstavljaju bitan izvor finansiranja banaka i ostalih finansijskih institucija. Fondovi novčanog tržišta su predmet regulacije EU, ali i domaćih regulatornih i zakonodavnih odredbi. Preduzeća posebne namene su definisana ECB regulativom i finansiraju se emisijom utrživih hartija od vrednosti. Ova kategorija pravnih lica je u poslednje tri godine smanjila volumen transakcija za 19\%, odnosno sa 500 mlrd EUR na 402 mlrd EUR. Kategorija ostalih finansijskih posrednika (preduzeća finansijskog lizinga, holding kompanije i preduzeća osnovana za specifične aktivnosti) predstavlja institucije koje nisu angažovane $\mathrm{u}$ aktivnostima sekjuritizacije (Financial Stability Board, 2015).

\section{ZAKLJUČAK}

Globalna finansijska kriza je ukazala na činjenicu da problemi izvan bankarskog sektora, prepoznati kao bankarstvo u senci, mogu imati dalekosežne posledice po svetsku ekonomiju. Samim tim što se aktivnosti banaka u senci suštinski realizuju na vrlo sličan (ako ne i isti) način kao što je to slučaj sa tradicionalnim bankama, ove institucije ostaju izvan okvira zvaničnih regulatornih sistema te shodno tome urušavaju 
stabilnost postojećih sistema uz prisutnu opasnost da se taj efekat prelije na više zemalja, čak i na ceo svet. Enormni rast vrednosti transakcija koje obavljaju banke u senci je dokazan kako kroz globalne trendove kretanja tako i kroz pojedine empirijske slučajeve, u radu su prikazani primeri Kine i Irske sa akcentom na ulogu banaka u senci u odnosu na regularne bankarske institucije. Iz postojećeg ugla posmatranja, opasnost da se transakcije banaka u senci u značajnoj meri pojave na srpskom tržištu trenutno ne postoje, imajući u vidu važeću zakonsku regulativu i postojeću praksu to nije moguće. Međutim, postoji potreba da se obim transakcija banaka u senci sagleda na celovit način, jer ove institucije donose i nov, drugačiji pristup tržištima, istovremeno naglašavajući potrebu da se teorijski i empirijski pristup kombinovano koriste u cilju razumevanja svih finansijskih transformacija koje bankarstvo u senci sa sobom nosi.

\section{LITERATURA}

Bundgard, L.A., \& Jorgensen, P.N. (2013). Shadow banking in Europe and the systemic risk involved: An empirical approach. Aarhus University. BSS. Department of Economics and Business. Preuzeto 14.09.2016. sa http://pure.au.dk/ portal-asb-student/files/56696708/Text.pdf

Ekapija. (2015). Bankarstvo iz senke "teško" 80.000 mlrd USD. Preuzeto 14.09.2016. sa http://www.ekapija.com/website/ sr/page/1289725/Bankarstvo-iz-senke-te\%C5\%A1ko-80000-mlrd-USD

European Banking Authority. (2015). Guidelines on limits on exposures to shadow banking entitites. Preuzeto 14.09.2016. sa https://www.eba.europa.eu/documents/10180/1310259/ EBA-GL-2015-20+GL+on+Limits+to+Exposures+to+Sh adow+Banking+Entities.pdf/f7e7ce6b-7075-44b5-9547$5534 c 8 c 39 a 37$
European Central Bank. (2012). Shadow banking in the euro area: an overview. Preuzeto 14.09.2016. sa

https://www.ecb.europa.eu/pub/pdf/scpops/ecbocp133. pdf?4e7d9b9457759addc96d58dd6dcf1891

Financial Stability Board. (2011). Shadow Banking: Strengthening Oversight and Regulation. Preuzeto 14.09.2016. sa http://www.fsb.org/wp-content/uploads/r_111027a. pdf?page_moved $=1$

Financial Stability Board. (2014). Global Shadow Banking Monitoring Report 2014. Preuzeto 14.09.2016. sa http://www.fsb. org/wp-content/uploads/r_141030.pdf?page_moved=1

Financial Stability Board. (2015). Global Shadow Banking Monitoring Report 2015.

Preuzeto 14.09.2016. sa http://www.fsb.org/wp-content/ uploads/global-shadow-banking-monitoring-report-2015. pdf

IMF. (2014). Shadow Banking Is Boon, Bane for Financial System. Preuzeto 14.09.2016. sa http://www.imf.org/en/News/ Articles/2015/09/28/04/53/sopol100114a

Jiang, W. (2015). The Future of Shadow Banking in China. Jerome A. Chazen Institute of International business, Preuzeto 14.09.2016. sa http://www8.gsb.columbia.edu/ chazen/globalinsights/sites/globalinsights/files/Shadow\%20Banking\%20in\%20China_Chazen\%20Institute.pdf Mirković, V., \& Lukić, J. (2015). Mobilno bankarstvo kao inovacija u sektoru finansijskih usluga. Ekonomski vidici, 20 (2-3), 297-310.

Narodna banka Srbije. (2015). Zakon o bankama. Preuzeto 14.09.2016. sa http://www.nbs.rs/internet/latinica/20/ zakoni/kpb_banke_2015.pdf

Pozsar, Z., Adrian, T., Ashcraft, A., \& Boesky, H. (2010). Shadow Banking. Preuzeto 14.09.2016. sa https://www.newyorkfed. org/medialibrary/media/research/staff_reports/sr458.pdf

Wehinger, G. (2012). Bank deleveraging, the move from bank to market-based financing, and SME financing. Preuzeto 14.09.2016. sa http://www.oecd.org/finance/financial-markets/Bank_deleveraging-Wehinger.pdf

\section{SHADOW BANKING AS A POTENTIAL FACTOR OF FINANCIAL SYSTEM INSTABILITY}

\section{Abstract:}

The last decade of XXI century, especially after the global financial crisis, has been marked by the intensive process of transitioning from traditional banking institutions toward non-banking institutions, i.e. so-called shadow banking. The Financial Stability Board (FSB) defined the term "shadow banking" and significantly assisted in identifying the major drivers of changes implied by the presence of non-banking institutions in the segments covered by traditional banking. The main drivers of changes could be identified in several spheres, such as: regulatory requirements, technological progress and favorable macroeconomic environment. Shadow banking is much more present in the markets of developed countries, reaching above average volumes and pinpointing to their increased importance. Although in keeping with the Law on Banks of the Republic of Serbia banks are the only institutions that can be engaged in loan disbursement and credit card issuance as well as deposit collection, there is a likelihood that shadow banking will also appear in the domestic market. This paper is aimed at reviewing major characteristics of shadow banking, existing trends in its movement and analysis of its potential impact on the stability of financial systems. Furthermore, the paper is intended for experts in the area of banking and financial management, as well as, broader scientific society, concerned with the issue of regulating the areas, such as shadow banking, which are currently beyond the reach of official regulatory bodies.

\section{Keywords:}

shadow banking, traditional banking, innovations, stability, financial system. 